\title{
Analysis of the perception of foreign tourists about Turkish cuisine through the word association test: The case of Cappadocia region
}

\author{
Serkan Yiğit*, Nilüfer Şahin Perçin
}

ABSTRACT

Keywords:

Turkish cuisine,

Perception,

Word association test,

Cappadocia

Article History:

Submitted: 25.01.2020

Accepted: 01.12.2020

\begin{abstract}
Countries, which are rich in historical, natural, and cultural, are advantageous in terms of tourism compared to other countries. Cuisines, one of the cultural richness, attracted the attention of tourists in recent years. With its historical and cultural background, Turkish cuisine has always made itself known amongst the world's cuisines. Considering the increasing popularity of Turkish cuisine; of foreign tourists coming to Turkey, their thoughts about Turkish cuisine has become extremely important. The aim of this study is to determine opinions of foreign tourists coming to Cappadocia region of Nevşehir about Turkish cuisine. In order to determine their decision Word Association Test (WAT) was applied. As a result, Turkish cuisine offers delicious, spicy, various, healthy foods, but is not well-known.
\end{abstract}

\section{Introduction}

People can participate in the tourism movement in order to see the authentic and cultural values they have not seen before and gain experience (Kim, Eves, \& Scarles, 2009). As a result, there is a motivation for people to experience the local foods and beverages of a country (Arslan, 2010; Ting et al., 2019). The desire of today's tourists to recognize different cultures causes the national cuisine cultures to be the center of attention. This may also affect the travel motivations of tourists. Tourists organize trips not only to see different places but also to experience food from different cultures. Experiencing foods belonging to different cultures can be interpreted not only as a physiological need but also as a sociological reading of culture over the cuisine (Bucak, Yiğit, and Okat, 2019). Tourists in increasing gastronomic tourism mobility often try local dishes in activities to get to know different cultures (Fields, 2002; Smith \& Xiao, 2008; Seyitoğlu and Çalışkan, 2014; Yuan, 2015; Ahmad et al., 2020).
Although the action of eating is important for people to continue their lives, the content of the food, how it is prepared and served differs from each society (Albayrak, 2013). These differences create the features of the cuisines and cause them to differ from other cuisines (Sanchez-Canizares and Castillo-Canalejo, 2015; Tseng et al., 2015). Differences among cuisines create an element of attraction in tourism marketing (Kivela and Crotts, 2006; Okumus, Okumus, \& McKercher, 2007). Tourism is one of the important means of economic, social, human, and political cooperation between countries. Tourism is also an industry that enables communities to get to know each other better with social and cultural values (Şanlıer, 2005). In tourism mobility; cuisines, one of the cultural values, come to the fore. Tourists experience through the national's cuisine and as a result of these experiences they start sympathizing with the country and the society (Çakıcı and Eser, 2016). In fact, national cuisines can also be used as a marketing tool in promoting the country (Gökdemir, 2009). 
At this point, Turkish cuisine is considered as one of the well-known cuisines in the world (Belge, 2001). Turkish cuisine, with the diversity of Central Asian and Anatolian lands, the interaction of Turks with other nations in the historical process. New flavors that developed in the palaces of the empires such as the Seljuk and the Ottoman, played a role in gaining the new structure of the Turkish cuisine (Ministry of Culture and Tourism, 2020). The main general features of Turkish cuisine are (Önçel, 2015):

- Pastries have an important role in Turkish cuisine.

- Vegetables use in Turkish cuisine; it is common to cook it with meat, onions, tomatoes, and tomato paste.

- Olive oil s frequently used in Turkish cuisine. Olive oil is mostly used in Western Anatolian cuisine. The use of butter and animal oils is also common in Turkish cuisine.

- Spices are common in Turkish cuisine. Although it varies from region to region, spices such as chili peppers, mint, and thyme are used.

When the Turkish cuisine is examined in terms of its general characteristics; it is a cuisine based on agricultural and animal products in general, differing in geographical regions, special days and ceremonies and social structure in the historical development process and the effects of the religion of Islam are also seen (Güler, 2007). There are traditional foods that are important for the nutrition of countries with culinary and food culture and which are known to be national-specific (Sormaz et al., 2019). Traditional tastes that come to mind when it comes to Turkish cuisine; examples of foods and beverages such as pita, lahmacun, meatballs, buttermilk, baklava, sherbets, döner, and kebabs (Ministry of Culture and Tourism, 2020).

Knowing the opinions of foreign tourists coming from different cultures about Turkish cuisine can provide clues about the expectations, wishes, and needs of the tourists. With the word association test used in this study, the general judgments of the participants about Turkish cuisine can be determined. One of the main purposes of the word association test is to reveal instant thoughts about a topic. With this study, it is planned to fill the gap in the literature. Therefore, the purpose of this study is; to determine the opinions of foreign tourists visiting the Cappadocia region of Nevşehir about Turkish cuisine with the word association test (WAT)

\section{Literature Review}

When the literature on the subject is examined, many studies have been carried out in which Turkish cuisine is evaluated from the perspective of foreign tourists. These studies and their results are listed below.

Akman and Hasipek (1999) examined the attitudes and behaviors of foreign tourists about Turkish cuisine in their study. Tourists who participated in the study, among the reasons for coming to Turkey, the Turkish cuisine has taken seventh place. It was determined that $94 \%$ of the tourists had consumed any food or beverage belonging to Turkish cuisine before. Özdemir and Kinay (2004) conducted a study in order to determine the views of foreign tourists on Turkish cuisine. Tourists participating in the study gave a positive opinion about Turkish cuisine in general. Tourists described Turkish cuisine as delicious, diverse, interesting, hygienic, and nutritious. Some of the tourists, on the other hand, stated negative opinions that Turkish cuisine is fatty, too much tomato paste, and spicy. Şanlier (2005) conducted a study to examine the views of local and foreign tourists on Turkish cuisine. As a result, it has been determined that foreign tourists find Turkish cuisine delicious, interesting, fatty, and spicy. Albayrak (2013) tried to determine the views of tourists from different nationalities on Turkish cuisine. According to the data obtained, tourists; Although they find Turkish food delicious, fragrant, appetizing, satisfying, good-looking, different, healthy, and safe, they also found it too tomato paste, spicy, fatty and calorie. Birdir and Akgöl (2015) have carried out their study they evaluated the gastronomic experience of foreign tourists visiting Turkey. In the results of the study; The food tasting request specific cause of Turkish cuisine to foreign tourists prefer Turkey have determined that it is in third place. It was emphasized that the first choice of foreign tourists participating in the study was restaurants serving local foods. Çakıcı and Eser (2016) evaluated Turkish cuisine from the perspectives of foreign kitchen chefs in their studies. In this context, foreign cuisine chefs have liked Turkish cuisine in terms of portion, spice variety, nutritional value, quality, and taste. On the other hand, the chefs have negative opinions about Turkish cuisine; hygiene, digestive difficulties, and excessive use of sugar. 


\section{Methodology}

The word association test (WAT) was applied in order to determine the opinions of foreign tourists about Turkish cuisine. Participants who have tasted Turkish cuisine were included in the study. As part of the study, the word association test was applied to 59 foreign tourists. Data collected between 10 January to 1 March in 2019, through face-to-face interviews with tourists. The data analyzed in a qualitative data analysis program. The word association test is defined as the "measurement and evaluation method that tries to determine the meaning and adequacy levels of the information and relationships that arise in the consciousness of the participants towards certain events and facts" (Işıklı, Taşdere \& Göz, 2011). Özatlı and Bahar (2010), defined the word association test as "one of the measurement and evaluation techniques that enables the observation of the cognitive structure and the network related to the information formed in the mind and determines whether the relationships between the concepts in memory are sufficient and meaningful". In recent years, studies have been carried out in the field of tourism through the word association test (Keskin \& Örgün, 2015; Keskin, Örgün \& Akbulut, 2017; Akyurt, 2019; Onat and Keskin, 2019, Karakuş, Onat \& Güneren-Özdemir, 2020). In the word association test used as a data collection tool; Turkish cuisine is listed 10 times in a row on a page. Foreign tourists participating in the study

Table 1: Demographic Features of the Participants

\begin{tabular}{|l|l|l|}
\hline Variables & $\mathbf{n : 5 9}$ & \% \\
\hline Gender & & \\
\hline Female & 22 & 37.3 \\
\hline Male & 37 & 62.7 \\
\hline Country & 14 & 23.7 \\
\hline United States of America & 8 & 13.6 \\
\hline South Korea & 8 & 13.6 \\
\hline Germany & 6 & 10.1 \\
\hline United Kingdom & 6 & 10.1 \\
\hline Russia & 5 & 8.5 \\
\hline China & 4 & 6.8 \\
\hline Italy & 4 & 6.8 \\
\hline France & 1 & 1.7 \\
\hline Ukraine & 1 & 1.7 \\
\hline Spain & 1 & 1.7 \\
\hline Lebanon & 1 & 1.7 \\
\hline Egypt & 14 & 23.7 \\
\hline
\end{tabular}

Source: Authors

were informed about the word association test and during the application of the test, participants were asked to write the relevant concepts come to mind within 30 seconds. The 30 second time period was determined as the most suitable time period in the pretests performed in previous studies (Kempa and Nicolas, 1983; Yalvaç, 2008; Polat, 2013; Keskin and Örgün, 2015).

\section{Results}

The opinions of foreign tourists about Turkish cuisine were carried out with 59 participants with the word association test. The analysis results are given below.

Table 1 shows the demographic characteristics of foreign tourists participating in the word association test. $62.7 \%(\mathrm{n}: 37)$ of the participants are male and $37.3 \%$ (n: 22) are female. The majority of the participants; $23.7 \%$ ( $n: 14)$ came from countries such as the United States of America, 13.6\% (n: 8) South Korean, and Germany, 10.1\% (n: 6) from the United Kingdom, and Russia.

Table 2: Word Association Test Results of Turkish Cuisine

\begin{tabular}{|l|l|l|l|}
\hline Words & \\
& & \\
& & \\
& &
\end{tabular}

In Table 2; It is seen that 59 foreign tourists participating in the study associate Turkish cuisine with 466 words. Participants were able to fully participate in the first, second, third, and fourth words while establishing a word relation with Turkish cuisine. It is seen that the participants started to have difficulty in finding words related to Turkish cuisine starting from the fifth word. This reveals that foreign tourists can say at least four words associated with Turkish cuisine.

In Table 3, 56 words, which foreign tourists think are related to Turkish cuisine, have been obtained. 52 words not related to Turkish cuisine were not included in the analysis. The first five words considering the Turkish cuisine are; delicious (n:42), spicy ( $\mathrm{n}: 30)$, not well known ( $: 27)$, diverse $(n: 24)$, and healthy $(n: 17)$. Tourist perception of Turkish cuisine, it as cuisine that offers delicious, spicy, varied, healthy food, but is not well known. 
Table 3: Words Associated with Turkish Cuisine of the Participants and the Frequency of These Words

\begin{tabular}{|c|c|c|c|c|c|}
\hline No & Word & $\mathbf{n}$ & No & Word & $\mathbf{n}$ \\
\hline 1 & delicious & 42 & 29 & Turkish delight & 5 \\
\hline 2 & spicy & 30 & 30 & Nusret & 4 \\
\hline 3 & not well known & 27 & 31 & famous & 4 \\
\hline 4 & diverse & 24 & 32 & meze & 4 \\
\hline 5 & healthy & 17 & 33 & pide & 3 \\
\hline 6 & amazing & 14 & 34 & different & 3 \\
\hline 7 & traditional & 13 & 35 & hard to find & 3 \\
\hline 8 & best breakfast & 12 & 36 & historical & 3 \\
\hline 9 & fresh & 12 & 37 & homemade & 3 \\
\hline 10 & need promotion & 12 & 38 & not easy to cook & 3 \\
\hline 11 & baklava & 11 & 39 & sweet & 3 \\
\hline 12 & kebab & 11 & 40 & salty & 3 \\
\hline 13 & unique ingredients & 10 & 41 & bread & 2 \\
\hline 14 & affordable & 9 & 42 & dolma & 2 \\
\hline 15 & best & 9 & 43 & filling & 2 \\
\hline 16 & lamb & 9 & 44 & fusion cuisine & 2 \\
\hline 17 & not familiar & 9 & 45 & multicultural & 2 \\
\hline 18 & bad presentation & 8 & 46 & not diverse & 2 \\
\hline 19 & good & 8 & 47 & not popular & 2 \\
\hline 20 & $\begin{array}{l}\text { not only kebab and } \\
\text { doner }\end{array}$ & 8 & 48 & plentiful & 2 \\
\hline 21 & big portions & 7 & 49 & wine & 2 \\
\hline 22 & interesting & 7 & 50 & rice & 2 \\
\hline 23 & colorful & 6 & 51 & rich & 2 \\
\hline 24 & döner kebab & 6 & 52 & similar & 2 \\
\hline 25 & fatty & 6 & 53 & special & 2 \\
\hline 26 & beef & 5 & 54 & surprising & 2 \\
\hline 27 & halal & 5 & 55 & vegetable & 2 \\
\hline \multirow[t]{2}{*}{28} & similar tastes & 5 & 56 & yogurt & 2 \\
\hline & & & & Other & 52 \\
\hline
\end{tabular}

* Words that are close to each other are included in the same group. Source: Authors

The word that attracts attention in the table are the expressions "not well known" (n: 27) and "need promotion" (n: 12). Based on these words, the participants think that Turkish cuisine is not promotion enough.



Figure 1: Word Cloud Representation of Participants' Expressions About Turkish Cuisine
Figure 1 shows the word cloud representation of the words expressed about Turkish cuisine. In the figure, the words with the highest number of repetitions are seen as more big letters.

Table 4: Word Groups Expressed About Turkish Cuisine

\begin{tabular}{|c|c|}
\hline $\begin{array}{l}\text { Positive Words About } \\
\text { Turkish Cuisine }\end{array}$ & $\begin{array}{l}\text { delicious, diverse, healthy, amazing, } \\
\text { traditional, best breakfast, fresh, unique } \\
\text { ingredients, affordable, best, lamb, } \\
\text { good, not only kebab and döner, big } \\
\text { portions, interesting, colorful, halal, } \\
\text { Turkish delight, famous, different, } \\
\text { historical, homemade, sweet, } \\
\text { multicultural, plentiful, wine, rich, } \\
\text { special, surprising }\end{array}$ \\
\hline $\begin{array}{l}\text { Negative Words About } \\
\text { Turkish Cuisine }\end{array}$ & $\begin{array}{l}\text { spicy, not well known, need promotion, } \\
\text { not familiar, bad presentation, fatty, } \\
\text { similar tastes, hard to find, not easy to } \\
\text { cook, salty, } \\
\text { not diverse, not popular, similar }\end{array}$ \\
\hline
\end{tabular}

Source: Authors

The words about Turkish cuisine obtained by the word association test are divided into groups in Table 4. The words are divided into two groups as positive and negative words about Turkish cuisine.

\section{Discussion and Conclusion}

Within the scope of this study, which aims to analyze the views of foreign tourists coming to the Cappadocia region on Turkish cuisine using the word association method. The participants generally expressed a positive opinion about Turkish cuisine. This situation is similar to the study of Özdemir and Kınay (2004). The words delicious, spicy, not well-known diverse, and healthy, which are among the five most repeated words that obtained with the word association test, are Özdemir and Kınay (2004), Şanlıer (2005), Albayrak (2013), and Çakıcı and Eser (2016) parallel with the results of their work. In this study, the frequently repeating words not wellknown and not only kebab and döner, which are different from other studies, emphasize the lack of marketing and promotional activities of Turkish cuisine.

Turkish cuisine has a special place among world cuisines with its historical knowledge and cultural values. Turkish cuisine, fed from Anatolian lands that have hosted different civilizations for years, is a kind of living fusion cuisine. Due to such features of Turkish cuisine can leave memorable effects on people who experience Turkish cuisine. Within the scope of the study carried out, thoughts about Turkish cuisine were obtained through the word association test with 59 foreign tourists who experienced Turkish cuisine. When the five most repeated words are examined; The most repetitive 
word was the fact that the participants had "delicious" foods, one of the greatest features of Turkish cuisine. The second word that repeats the most is the word "spicy". Although Turkish cuisine varies from region to region, it is thought that this word is among the most repetitive words due to the high usage of spices. The word "not well known" is among the words obtained within the scope of the study. It was also revealed in this study that there are deficiencies in the promotion and marketing of Turkish cuisine, which has been discussed for many years. The word "need promotion" also supports this situation, although it is not among the most repeated words. Besides the historical and cultural richness of Turkish cuisine, another outstanding feature is the richness of food and drink. This situation was supported by the fourth most repeating word "diverse" in the study. The fifth most repeating word was the word "healthy". The experience of Turkey's four seasons and each season's unique food that is thought to make healthy food advantageous for the Turkish cuisine.

When the negative words among the words expressed about Turkish cuisine are examined; words related to the promotion of Turkish cuisine and sense of taste come to the fore. Such negative word groups are also seen as thoughts that need to be examined carefully.

Positive words were spoken about Turkish cuisine; written and visual tools should be included in the promotions of Turkish cuisine abroad. In this way, the interest of other people in Turkish cuisine can be increased. Comparisons can be made by performing such studies in different destinations in Turkey. In addition, after experiencing and experiencing the food of Turkish cuisine, participants can take a word relationship test to see the changes in between.

\section{References}

Akman, M., \& Hasipek, S. (1999). Yabancı turistlerin Türk mutfağı ile ilgili tutum ve davranışları. Beslenme ve Diyet Dergisi, 28(2), 47-53.

Akyurt, H. (2019). Turizm lisans öğrencilerinin kelime ilişkilendirme testi yöntemi ile turizm eğitimi algılamalarının ölçülmesi: Giresun Üniversitesi örneği. Türk Turizm Araştırmaları Dergisi, 3(3), 759-774.

Albayrak, A. (2013). Farklı milletlerden turistlerin Türk mutfağına ilişkin görüşlerinin saptanması üzerine bir çalışma. Journal of Yaşar University, 30 (8), 5049-5063.

Arslan, Ö. (2010). Yabancı turistlerin yiyecek-içecek işletmeleri, personeli ve Türk mutfağına ilişkin görüşlerinin değerlendirilmesi: Alanya örneği.
Unpublished Master Thesis, Gazi Üniversitesi Eğitim Bilimleri Enstitüsü, Ankara.

Belge, M. (2001). Tarih boyunca yemek kültürü. İletişim Yayınları: İstanbul.

Birdir, K., \& Akgöl, Y. (2015). Gastronomi turizmi ve Türkiye'yi ziyaret eden yabancı turistlerin gastronomi deneyimlerinin değerlendirilmesi. Issletme ve Íktisat Calışmaları Dergisi, 3(2), 57-68.

Bucak, T., Yiğit, S., \& Okat, Ç. (2019). Türk mutfağı tanıtım faaliyetlerinin gastrodiplomasi kavramı açısından incelenmesi. 20. Ulusal ve 4. Uluslararası Turizm Kongresi Bildiriler Kitabı, Eskişehir.

Çakıcı, A. C., \& Eser, S. (2016). Yabancı mutfak şefleri gözüyle Türk mutfağına ilişkin bir değerlendirme. Journal of Tourism and Gastronomy Studies, 4 (Special Issue1), 215-227.

Fields, K. (2002). Demand for the gastronomy tourism product: Motivational factors. A. Hjalager ve G. Richards (Eds), Tourism and Gastronomy, 37-50. London: Routledge.

Gökdemir, A. (2009). Mutfak hizmetleri yönetimi. Ankara: Detay Yayıncılık.

Güler, S. (2007). Türk mutfağının değişim nedenleri üzerine genel bir değerlendirme. I. Ulusal Gastronomi Sempozyumu ve Sanatsal Etkinlikler, Antalya.

Işıklı, M., Taşdere, A., \& Göz, N. L. (2011). Kelime ilişkilendirme testi aracılığıyla öğretmen adaylarının Atatürk ilkelerine yönelik bilişsel yapılarının incelenmesi. Uşak Üniversitesi Sosyal Bilimler Dergisi, 4(1), 50-72.

Karakuş, Y., Onat, G., \& Güneren-Özdemir, G. (2020). Yerel Halkın Gastronomi Turizmi Çağrışımları ve Beklentileri: Göreme Kasabası Örneği . Journal of Tourism and Gastronomy Studies, 2020 (3), 21792201. https://doi.org/10.21325/jotags.2020.655

Kempa, R. F., \& Nicolas, C. E. (1983). Problem solving ability and cognitive structure - an explanatory investigation. Europan Journal of Science Education, 5, 171-184.

Keskin, E. \& Örgün, E. (2015). Kelime ilişkilendirme testi aracılığıyla sürdürülebilir turizm olgusunun kavramsal analizi: Ürgüp örneği. Journal of Tourism and Gastronomy Studies, 3(1), 30-40.

Keskin, E., Örgün, E., \& Akbulut, B. A. (2017). Gastronomi kavramının kelime ilişkilendirme testi aracılığıly analizi. Journal of Tourism and Gastronomy Studies, 5(3), 255-267.

Kivela, J., \& Crotts, J. C. (2006). Tourism and gastronomy: gastronomy's influence on how tourists experience a destination. Journal of Hospitality and Tourism Research, 30(3), 354377. 
Ministry of Culture \& Tourism. (2020). Geleneksel mutfak.

https://www.kulturportali.gov.tr/turkiye/genel/ne yenir?illd=0andkeyword=andetiket=andhariciEt ket=andkategori $=0$ andgorsel $=0$ andsayfa $=3$ andsa yi=12. (Erişim Tarihi: 07.02.2020).

Ministry of Culture and Tourism. (2020). Genel özellikleriyle Türk mutfak kültürü. https://aregem.ktb.gov.tr/TR-12762/genelozellikleriyle-turk-mutfak-kulturu.html. (Erişim Tarihi: 06.02.2020)

Onat, G., \& Keskin, E. (2019). Organik gıda kavramının kelime ilişkilendirme testi aracılığıyla analizi. Journal of Tourism and Gastronomy Studies, 7(4), 3275-3289.

Önçel, S. (2015). Türk mutfağı ve geleceğine ilişkin değerlendirmeler. Journal of Tourism and Gastronomy Studies. 3(4), 33-44.

Özatlı, N. S., \& Bahar, M. (2010). Öğrencilerin boşaltım sistemi konusundaki bilişsel yapılarının yeni teknikler ile ortaya konması. Abant Izzet Baysal Üniversitesi Dergisi, 10(2), 9-26.

Özdemir, B., \& Kınay, F. (2004). Yabancı ziyaretçilerin Türk mutfağına ilişkin görüşleri: Antalya'yı ziyaret eden Alman ve Rus turistler üzerine bir araştırma. Gazi Üniversitesi Ticaret ve Turizm Eğitim Fakültesi Dergisi, 2(5), 1-34.

Polat, G. (2013). 9. Sınıf öğrencilerinin çevreye ilişkin bilişsel yapılarının kelime ilişkilendirme test tekniği ile tespiti. NEF-EFMED, 7(1), 97-120.

Şanlıer, N. (2005). Yerli ve yabancı turistlerin Türk mutfağı hakkındaki görüşleri. Gazi Ĕgitim Fakültesi Dergisi, 25(1), 213-227.

Seyitoğlu, F., \& Çalışkan, O. (2014). Turizm literatüründe Türk mutfağı üzerine yapılan araştırmaların değerlendirilmesi. Journal of Tourism and Gastronomy Studies, 2(4), 23-35.

Sormaz, Ü., Onur, N., Güneş, E., \& Nizamlığlu, H. F. (2019). Türk mutfağı geleneksel ürünlerinde yöresel farklılıklar: Tarhana örneği. Aydın Gastronomy, 3(1), 1-9.

Yalvaç, G. H. (2008). İsbirlikli ögrrenme yaklaşımının ögretmen adaylarının çevreye ilişkin zihinsel yapılarına etkisi (Unpublished Master Thesis). Abant İzzet Baysal Üniversitesi, Bolu.

Yuan, S. (2015). Reflections on local specialties and gastronomic tourism. Chinese Studies, 4, 15-19.

Kim, Y. G., Eves, A., \& Scarles, C. (2009). Building a model of local food consumption on trips and holidays: A grounded theory approach. International Journal of Hospitality Management, 28 (3), 423-431.

Ting, H., Fam, K. S., Hwa, J. C. J., Richard, J. E., \& Xing, N. (2019). Ethnic food consumption intention at the touring destination: the national and regional perspectives using multi-group analysis. Tourism Management, 71, 518-529.

Sanchez-Canizares, S., \&Castillo-Canalejo, A. M. (2015). A comparative study tourist attitudes towards culinary tourism in Spain and Slovenia. British Food Journal, 117(9), 2387-2411.

Tseng, C., Wu, B., Morrison, A. M., Zhang, J., \& Chen, Y. C. (2015). Travel blogs on China as a destination image formation agent: A qualitative analysis using leximancer", Torism Management, 46, 347358.

Okumus, B., Okumus, F., \& McKercher, B. (2007). Incorporating local and international cuisines in the marketing of tourism destinations: The cases of Hong Kong and Turkey. Tourism Management, 28(1), 253-261.

Ahmad, M.S., Jamil, A., Latif, K.F., Ramayah, T., Ai Leen, J.Y., Memon, M., \& Ullah, R. (2020). Using food choice motives to model Pakistani ethnic food purchase intention among tourists. British Food Journal, 122(6), 1731-1753.

Smith, S. L., \& Xiao, H. (2008). Culinary tourism supply chains: A preliminary examination. Journal of Travel Research, 46(3), 289-299. 


\title{
INFO PAGE
}

\section{Analysisi of the perception of foreign tourists about Turkish cuisine through the word association test: The case of Cappadocia region}

\begin{abstract}
Countries which are rich in historical, natural and cultural riches, are advantageous in terms of tourism compared to other countries. Cuisines, one of the cultural riches, have attracted the attention of tourists in recent years. With its historical and cultural background, Turkish cuisine has always made itself known amongst the world's cuisines. Considering the increasing popularity of Turkish cuisine; of foreign tourists coming to Turkey, their views about Turkish cuisine has become extremely important. The purpose of this study; To determine the opinions of foreign tourists coming to Cappadocia region of Nevşehir about Turkish cuisine. For this purpose, foreign tourists; in order to determine their opinions about Turkish cuisine, Word Association Test (WAT) was applied. As a result of the words obtained; Turkish cuisine by the participants; It is seen as a cuisine that offers delicious, spicy, various, healthy foods, but is not well known.
\end{abstract}

Keywords: Turkish cuisine, Perception, Word association test, Cappadocia

\section{Authors}

Full Name

Author statement: Author(s) declare(s) that All procedures performed in studies involving human participants were in accordance with the ethical standards of the institutional and/or national research committee and with the 1964 Helsinki declaration and its later amendments or comparable ethical standards.

Ethics Committee Satatement: This paper does not required ethics committee report.

Justification: This research was conducted before January 1, 2020. For this reason, it is exempt from "'ULAKBIM TRDizin"' criterion. 